\title{
Correction to: Cancer-associated fibroblasts promote the survival of irradiated nasopharyngeal carcinoma cells via the NF-kB pathway
}

Weiqiang Huang ${ }^{1+}$, Longshan Zhang ${ }^{1+}$, Mi Yang ${ }^{1}$, Xixi Wu ${ }^{1}$, Xiaoqing Wang ${ }^{1}$, Wenqi Huang ${ }^{2}$, Lu Yuan$^{2}$, Hua Pan ${ }^{1}$, Yin Wang ${ }^{1}$, Zici Wang ${ }^{3}$, Yuting Wu², Jihong Huang ${ }^{2}$, Huazhen Liang ${ }^{4}$, Shaoqun Li', Liwei Liao ${ }^{1}$, Laiyu Liu ${ }^{2 *}$ and Jian Guan ${ }^{1 *}$

\section{Correction to: J Exp Clin Cancer Res 40, 87 (2021) https://doi.org/10.1186/s13046-021-01878-x}

Following publication of the original article [1], the authors and publisher identified errors in the typesetting of the supplementary material. Whilst the supplementary file captions were correct, the supplementary material files had been ordered incorrectly within the article.

The original article has been corrected.

\section{Author details}

'Department of Radiation Oncology, Nanfang Hospital, Southern Medical University, Guangzhou, Guangdong, China. ${ }^{2}$ Chronic Airways Diseases Laboratory, Department of Respiratory and Critical Care Medicine, Nanfang Hospital, Southern Medical University, Guangzhou, Guangdong, China. ${ }^{3}$ Department of Obstetrics and Gynecology, The First Affiliated Hospital of Guangzhou Medical University, Guangzhou, Guangdong, China. ${ }^{4}$ Department of Oncology, Maoming People's Hospital, Maoming, Guangdong, China. ${ }^{5}$ Department of Radiation Oncology, Guangdong 999 Brain Hospital, Guangzhou, Guangdong, China.
Published online: 22 March 2021

\section{Reference}

1. Huang W, Zhang L, Yang M, et al. Cancer-associated fibroblasts promote the survival of irradiated nasopharyngeal carcinoma cells via the NF-KB pathway. J Exp Clin Cancer Res. 2021;40:87 https://doi.org/10.1186/s13046021-01878-x.

The original article can be found online at https://doi.org/10.1186/s13046021-01878-x.

* Correspondence: liuly5461@163.com; guanjian5461@163.com

†Weiqiang Huang and Longshan Zhang contributed equally to this work. ${ }^{2}$ Chronic Airways Diseases Laboratory, Department of Respiratory and Critical Care Medicine, Nanfang Hospital, Southern Medical University, Guangzhou, Guangdong, China

${ }^{1}$ Department of Radiation Oncology, Nanfang Hospital, Southern Medical University, Guangzhou, Guangdong, China

Full list of author information is available at the end of the article

(c) The Author(s). 2021 Open Access This article is licensed under a Creative Commons Attribution 4.0 International License, which permits use, sharing, adaptation, distribution and reproduction in any medium or format, as long as you give appropriate credit to the original author(s) and the source, provide a link to the Creative Commons licence, and indicate if changes were made. The images or other third party material in this article are included in the article's Creative Commons licence, unless indicated otherwise in a credit line to the material. If material is not included in the article's Creative Commons licence and your intended use is not permitted by statutory regulation or exceeds the permitted use, you will need to obtain permission directly from the copyright holder. To view a copy of this licence, visit http://creativecommons.org/licenses/by/4.0/. The Creative Commons Public Domain Dedication waiver (http://creativecommons.org/publicdomain/zero/1.0/) applies to the data made available in this article, unless otherwise stated in a credit line to the data. 